\title{
Wireless Communication: The Impact of Gsm on the Economic Lives of the Nigerian Rural Users
}

\author{
Chieme Azubuike \\ Department of Mass Communication \\ Rivers State College of Arts \& Sciences, Rumuola, Port Harcourt, Nigeria \\ Obiora Obiefuna \\ Leadway Assurance Co. Ltd,8 Igbodo Street, old G.R.A,Port Harcourt-Nigeria
}

Doi:10.5901/jesr.2014.v4n7p79

\begin{abstract}
In this paper, we examine the impact of wireless communication cum GSM on the economic lives of the Nigerian rural users, specifically, on the area of employment creation opportunity, crime reduction rate and their overall flow of income. As a result, this study employs a descriptive survey research design and while questionnaire administered to five hundred respondents randomly selected from five rural communities in Rivers State, Nigeria was used as a major instrument of data collection. The resultant findings clearly indicate that wireless communication cum GSM has considerable impact on the economic lives of the Nigerian rural users which also is a major tool for employment creation opportunity thereby diffusing the rate of crime in that area. Further findings conclude that GSM is an emerging communication industry in Africa, with Nigeria rated as one of the fastest growing markets in this field of communication. However, its impact on the Nigerian rural users is still relatively low. Hence, focus should be shifted to the utilization of the GSM for the development of rural communities in Africa, especially, Nigeria.
\end{abstract}

\section{Introduction}

The world is fast becoming a global village and a necessary tool for this process is communication, of which telecommunication is a key player. The level of development in the telecommunications industry around the globe is pervasive as one innovation replaces another in just matter of weeks. A major breakthrough is the wireless telephone system, which comes in either fixed wireless lines or the global system for mobile communication (GSM) (Wojuade, 2005).

Communication is fundamentally a major driver of any economy. Nigeria is not left out in the race for rapid developments, as the years of economic reversal as a result of mismanagement have had adverse effects on its rate of growth and development. The Nigerian telecommunications sector was wholly under-developed until the sector was deregulated under the military regime in 1992 with the establishment of a regulatory body, the Nigerian Communication Commission (NCC). Since then, the NCC has issued various licences to private telephone operators. These licences allow Private Telephone Operators (PTOS) to roll out both fixed wireless telephone lines and analogue mobile phones. The advent of democracy in 1999 however paved the way for the granting of GSM licences to three inaugural service providers viz MTN, ECONET (which earlier changed its name to V-MOBILE, Zain, Celtel and now Airtel) and NITEL PIC in 2001; with GLOBACOM joining in 2003 and more recentlyEmirates Telecommunications Corporation, branded trade name Etisalat, (http://www.radioeonics.com). Etisalat Nigeria commenced commercial operations on 23rd October 2008 with a promise to deliver innovative and quality services in Nigeria. Since then, Nigeria has continued to witness its innovative services (Wikipedia, free encyclopedia)

The development of GSM in the world was prompted by the need to provide seamless telecommunications through Europe. Back in the early 1980s, analogue mobile telephony was growing rapidly and operators find it increasingly difficult to interconnect the various networks in Europe (http://www.radioeonics.com). This was so because each implementation of the analogue service was fundamentally different, which made inter-working a serious challenge. To address this challenge, a study group called 'Group Special Mobile' (where GSM got its name) was formed and was tasked to provide a standardized system for mobile telephony. Today, GSM covers over 1.2 billion users on 630 
networks in over 210 countries, and is the fastest growing technology of all time.

In Nigeria, the National Economic Empowerment Development Strategy (NEEDS) highlights the nation's socioeconomic development aspirations. Specifically, it calls for the reform of the public sector, enabling a robust private sector-led economy and the implementation of an effective social charter to reduce poverty, create wealth, generate employment and re-orient national values. One fundamental feature is that it clearly delineates responsibilities between government and the private sector. While government would provide the enabling business and regulatory environment, the private sector is to invest in and manage ventures that stimulate and support socio-economic development.

Being aware of the catalytic role typically played by wireless communications in socio-economic development in Africa, GSM operators in Nigeria have developed a Joint Economic Development (JED) framework to support the government in the actualization of its objectives as set out in NEEDS. JED outlines the positive multiplier effects of wireless communications on virtually every sphere of human endeavour in the society, previews further prospects targets, highlights challenges and proffer solutions to such challenges and assigns specific roles to government and operators for further optimization of the benefits of GSM services (http://www.iec.org).

NEEDS target for the telecommunications sector includes:

i. Attainment of tele-density of 1.25 by the year 2007.

ii. The development of a national communication backbone and multi-media super-corridor.

Strategies identified for attaining these targets include the use of fiscal financial incentives to encourage investment, adoption of a local content policy in the manufacture of equipment, accessories and components as well as financial support for rural roll out and Internet access. Today, tele-density stands at about 1.15, there is significant improvement in rural telephone access penetration from just one (MTEL's) transmission backbone in 2001, at least four other backbones are constructed across the country today.

The summary is that the telecommunications sector has not in respect of tele-density exceeded its targets under NEEDS. This is essentially due to the advert of GSM services in 2001which has resulted in a dramatic increase in the total number of lines from just above 500,000 to over 60 Million today, accounting for about $91 \%$ of the total phone (fixed and mobile) market.

In Nigeria, there has been more expeditious roll out in rural areas covering over $50 \%$ government areas and at least 5,000 communities and villages. These developments inform Nigeria's present rating as the fastest growing telecommunications market in Africa (http://www.nigriabusinessinfo.com). There is no doubt that telecommunications sector has united the entire world. Within a second, business is on the wheel globally. Nevertheless, considering the previous relationship existing between the developed countries and the underdeveloped ones in the world, the pertinent questions now are: does this global system for mobile communication have any impact on the economic lives of the Nigerian rural users? Does it contribute to employment creation and crime reduction? This study is designed to address all these questions.

\section{Statement of Problem}

Many developing economies (Nigeria inclusive) and development agencies are focusing on extending ICT (Information and Communication Technology) infrastructure into rural areas, as they seek to encourage growth, alleviate poverty and overcome the perceived "digital divide" (Samuel et al, 2005). This need to extend ICT infrastructure to Africa's rural communities derives from the fact that the majority of the continent's population (up to $60 \%$ and more in some cases) live in these rural communities. Ndukwe (2006) captured the scenario in these words, "10,000 people have been directly employed by wireless mobile (GSM) operators in Nigeria and over, 1,000,000 indirect employments have been created around the telecom boom. These results should be extended to the rural communities to ensure sustainable increase in better livelihood and reduce the level of rural - urban migration. In view of the perceived importance of GSM to poverty alleviation especially in Nigeria, spirited efforts are being made by government, service providers and other development agencies in providing access to GSM services to many rural communities in Nigeria. The results of these efforts in the last five years have ushered in a tremendous growth in telephone ownership and use in some rural communities in Nigeria as many rural communities can now access three main service providers in Nigeria viz: MTN, Globacom and Airtel, (Souter et al., 2005) and more recently etisalat. This diffusion has brought wireless communication to new groups of users, users who were earlier excluded from the telecommunication system.

\section{Objectives of the Study}


In realizing the above goal, the following questions were used to amplify the objectives of this study:

1. Does the introduction of GSM have any impact on the economic lives of the Nigerian rural users?

2. Does the introduction of GSM provide employment opportunities to the Nigerian rural users?

3. Has the introduction of GSM reduce crime rate in rural areas in Nigeria?

\section{Literature Review and Conceptual Framework}

Mobile telecommunication is becoming one of the most important industries in the world. Although, perhaps, not the intent of introducing a new technology, the implementation of the GSM standard has directly and indirectly contributed to economic growth, led to the creation of new employment opportunities and contributed significantly to the GDP of many countries (Wojuade, 2005). The development of GSM in the world was prompted by the need to provide seamless telecommunications through Europe; Ajiboye, Adu, and Wojuade, (2007).

In Nigeria, rural tele-density is quite low and this has been attributed to the scarcity of wireless communication infrastructure in most parts of rural Nigeria a scenario that has created the digital divide between the urban and rural areas in Nigeria (Coyle, 2005). This situation has demonstrated the need for extension of ICT infrastructure especially GSM to the Nigerian rural communities.

However, a critical review of literature reveals contrasting findings by scholars on the impact of mobile phones on rural livelihoods, employment creation opportunity and poverty reduction. Studies have shown that there is a positive relationship between telecommunication infrastructure development and economic growth. Among these studies are International Telecommunication Union (ITU) (2003), Sridhar and Sridhar (2003 and 2004) and Noll (2000). Also, Woverman et al., 2005; Information for Development Studies, (2006); Lusting and Stern, (2000) have separately shown that Information Communication Technologies (ICT) such as mobile phones can have an impact on rural livelihoods and thereby on poverty in rural communities in developing countries.

However, Heeks (2005) maintains that the failure and massive underuse wireless communication cum GSM set up in rural communities have raised doubts over their relevance for rural poverty reduction and sustainability while the World Bank (2005) observes that making mobile phones availability in rural communities does not guarantee that poor people will and can use them to create and share knowledge that could help lift them out of poverty.

Between 1960 and 1985 the telecommunication sector consisted of the department of Post and Telecommunication (P\&T) in charge of the internal network and a limited liability company, the Nigerian External Telecommunication (NET) limited, responsible for the external telecommunication provided the gateway to the outside world. The installed switching capacity at the end of 1985 was about 200,000 lines as against the planned target of about 460,000 . All the exchanges were analogue with 1 phone line to 440 inhabitants, well below the target of 1 phone line to 100 inhabitants recommended by ITU (International Telecommunication Union) for developing countries. The quality of service was unsatisfactory. The phone was unreliable, congested, expensive and customer unfriendly.

Arising from the foregoing, in January 1985, the erstwhile Posts and Telecommunications department was split into Postal and Telecommunication divisions. The latter was merged with NET to form Nigeria Telecommunication Limited (NITEL), a limited liability company. The main objective of establishing NITEL was to harmonize the planning and co-ordination of the internal and external telecommunications services, rationalize investments in telecommunications development and provide accessible, efficient and affordable services. NITEL had roughly half a million lines available to over 100 million Nigerians after about 40 years. NITEL, the only national carrier as at then had a monopoly of the sector and was synonymous with epileptic services and bad management. On assumption of office on May 29, 1999, the President Olusegun Obasanjo administration swung into action to make it a reality the complete deregulation of the telecom sector, most especially the much touted granting of licences to GSM services providers and setting in motion the privatization of NITEL. This practical approach by the government to the telecom sector has made it possible for over 2.5 million Nigerians in the year 2005 to clutch GSM phones today (Nigeria Business Information, 2005). In addition to this, Nigeria is Africa's largest mobile market with more than 125 Million subscribers and market penetration of around $75 \%$ in early 2014. The rapid growth has led to problems with network congestion and quality of service, prompting the regulatory authority NCC to impose fines and sanctions (www.budde.com.au/Research/Nigeria-M)

Wireless Communication cum GSM mobile communication is one of the most explosive developments ever to have taken place in the telecommunications industry (Wojuade, 2006).

Audile (2000) describe GSM as part of evolution of wireless mobile communication that includes high speed circuit, switched data, general packets radio system and universal mobile telecommunication service. According to (Radioelectronic.com, 2006), the overall system definition for Wireless Communication describes not only the air 
interface but also the network.

International Engineering Consortium (2005) conceives GSM as a globally accepted standard for wireless communication. To them, it is the name of a standardization group established in 1982 to create a common European mobile telephone standard that would formulate specification for a Pan-European mobile cellular radio system operating at $900 \mathrm{MHz}$.

Ndukue cited in Wojuade (2006) periscopes a number of things on the development of Wireless Communication cum GSM in Nigeria. He explains that GSM actually came as a result of the choice of the operating companies who bided for the mobile licences. The operating companies quickly adopted GSM because of the obvious economic advantage. He concluded that since then GSM has spread even to the United States and such other places that traditionally did not have GSM at the beginning. And that it grew very fast and overtook fixed services within a short time and it is not just in Nigeria but all over the world.

ECONET wireless Nigeria Limited (ECONET which was one of the winners of GSM licences in Nigeria is a Zimbabwean based company with strong ties in South Africa. It is the fourth biggest mobile phone operator in Africa with a vast network in the southern part of the continent (Wojuade, 2006). In Nigeria, ECONET wireless international (EWI) now Airtel holds equity interest in ECONET of Zimbabwe and the South African government owned company Transnet.

Both companies hold a 60\% stakes in Nigeria affiliate (Masiyiwa, 2002). To Masiyiwa, Zimbabwean ECONET vision was to provide telecommunication to all Nigerians and its mission to serve Nigeria pioneering, developing and sustaining reliable, efficient and high quality telecommunication of uncompromising world class standard and ethics. Ajakaye (2005) explain that ECONET promises affordable charge and proposed to the government to allow them charge a connection fee of N20, 000,000.00 and air-time cost of N29 or N30 per minute which has been done.

In the same vein, Mobile Tele-communications Network Nigeria limited (MTN) is also one of the companies that own GSM licence in Nigeria. It began in 1994 with five countries and over three million customers in Uganda, Burundi, Swaziland, Cameroon and South Africa, leading Africa into a new age of economic developments using telecommunications as the spring board, which is the driving force behind MTN investment strategy for the continent. " Effective communication services are, particularly from a business perspective and nowhere more than in Nigeria which is developing into one of our most important trading" (Huel, 2001). However, it is on this fundamental truth that MTN has based its vision to become the leading provider of communication services in African continent linking quality services that is a catalyst for economic development. The success of MTN in Nigeria revolves round providing telecommunication across the countries. MTN's aim is to facilitate changes that have long term domestic benefits.

Apart from the obvious economic development, local infrastructure and facilities are up graded to improve the quality of life through wireless communication. Global communication was granted the licence as Nigeria's second national carrier in August 2002. The licences covers three broad categories which are: digital mobile licence (GSM); National carrier licence (fixed and non fixed wireless); and international Gateway licence. The licence will enable it to provide a high quality and world-class communication network that will provide any type of content voice, data and multimedia to consumers, subservice providers or enterprises. In line with the term of its licence, Globacom has incorporated GLO mobile limited to operate its digital mobile licence an addition that gives Globacom leverage to offer total quality products and services to its subscribers. No wonder its TV advert password is "building Africa's biggest and best network".

Emirates Telecommunication Corporation - Etisalat was founded in 1976 as a joint-stock company between International Aeradio Limited, a British Company and local partners. In 1983 the ownership structure changed - United Arab Emirates government held a 60\% share in the company and the remaining 40\% were publicly traded. In 1991 the UAE central government issued Federal Law No. 1, which gave the corporation the right to provide the telecommunications wired and wireless services in the country and between UAE and other countries. Etisalat Nigeria commenced commercial operations on 23 October 2008 with a promise to deliver innovative and quality services in Nigeria. Since then, Nigeria has continued to witness its unprecedented innovative, affordable and most subscriber friendly services.

Etisalat redefined speed with the roll-out of the unique 3.75G HSPA+ network and It has continued to prove itself an innovative company keen to give its subscribers the best possible experience at the most affordable price across all its area of coverage regions in Nigeria.

Its innovation has led to the growth of its active subscriber base to over 12 Million. Today, Etisalat has network coverage in all 36 states of the federation including Abuja, the federal capital territory as it continues to build its network and expand to new locations.

In March 2009, the NCC adjudged Etisalat as Nigeria's best network based on quality of service indices measured 
by the regulatory body; in 2011 after a similar assessment, Etisalat's network was once again rated best. To date, Etisalat Nigeria has won several industry awards for its innovation and quality service delivery. Some of these include: Brand of the Year, Fast Growing GSM Company of the Year, Best Marketing Company, Most Innovative Corporate Social Responsibility Company, Friendliest Tariff Mobile Operator and Best Telecoms Customer Service among others. Other operators of GSM in Nigeria are etisalat, Starcom, Orascom, etc (Blake, 2004 and Moholi, 2005).

All the operators have made communication effective and efficient in Nigeria. The services offered by these operators are prepaid phone card, contact line, voice mail, short messages services, fax and data communication service, conference calling, caller line identification, call diverse, call baring, call waiting, switching of cells, itemised bills and directory inquiry (Okoruwa, 2004).

At present a wide range of telecommunication services are offered in the country: Telephony; Telex; Cellular Mobile Telephony; Facsimiles; Gentex (Extension of telex terminals Leased Circuit; Alternate Leased Circuit; Maritime Mobile Service INMARSAT, shop shore, global mobile personal communications, high speed data transmission telegraphy, Public pay phones,

Value Added services, Business Network services and mobile radio trucking services etc.

\section{Impacts of GSM on Economic Lives of the Nigerian Rural Users}

According to Balogun (2000), GSM facilitates economic development as it provides easy and effective communication need to stimulate and promote trade between Nigeria and its foreign partners in the world. Even at home, it plays an advocacy role in communicating government programmes thereby linking to entire sectors of the economy together in order to achieve a common goal. Above all, it encourages investment which in the long run promotes employment opportunities. At microeconomic level, the sector's contribution to GDP increased by 53\% in 2003 making it the third highest contributor ahead of the financial sector which has been in operation for about 100 years. It has attracted foreign direct investment of about \$5billion. In respect of employment, over 135, 000 persons have been directly and indirectly employed by the operators and their distribution chain components while the industries support service sectors such as banking, insurance, consultancies (legal, accounting, HR, tax) haulage, shipping and IT, as well as the small and medium scale Enterprises (SME) segment of the economy have also witnessed very significant levels of increased activity.

According to a report in Nigeria Tribune Newspaper of July 16, 2004, government treasury has been boosted by payment of over 200 billion Naira in taxes and levies. National productivity has also been enhanced as travel times and associated risks have been reduced, business communications improve and the rural-urban divide narrow down. Social and family relationship and the security situation have also been significantly enhanced. A significant number of not-for profit corporate social responsibility (CRS) initiatives are being sponsored by the operators. In his own contribution Adeyeye cited in Wojuade (2005) said GSM has discouraged rural- urban migration, unlike before when rural dwellers were always eager to visit the cities. Now with GSM they travel to cities without boarding a vehicle. The introduction of GSM has also shown a potential for reducing crime and mortality rate. Accessibility to phone services ensure quick calls to security operations when the need arises as well as informing the fire stations during fire incidents to save live and properties. To Adomi (2006), GSM is used by Nigerians mostly to communicate with another. He explained that students used it to communicate with their course mates, friends, lecturers and family relatives. Additionally, family matters, finance, and academic matters constitute the topics/ subject of mobile communication for a majority of students, but mobile phone has limited the need for most of the students travel followed by facilitation of exchange information anytime the need arose.

Scotts (2004) reports a research carried out by Gamos Ltd on some characteristics of the use of telephones amongst rural and low income communities in some African Countries- Botswana, Ghana, and Uganda. The study reveals rural inhabitants and poorer urban users value phone services but do not use them very often compared to relatively more affluent users; over $40 \%$ of respondents in Uganda used mobile phones through friends and family and individuals; although a further $24 \%$ of people used mobile phone through teleshops; the result from all three countries were quite striking and consistent, demonstrating a strong preference for mobile phones rather than fixed line phones, and a preference for private phones rather than public access points. Scott cited in Adomi (2006) as well reports that educated people used phone more, have a strong intention to use phone in future, and have a more positive attitude towards phones.

As part of moving industry, telecommunication is expected to provide employment opportunities for the unemployed graduates and school leavers. The licensed operators in Nigeria such as mtn, airtel, glo, etisalat and the likes are still recruiting workers. It is against this background that the present study is design to examine the impact of 
wireless system of global communication on the economic lives of the Nigerian rural users and as well consider its implication for the emerging communication industries.

\section{Methodology}

This study adopted descriptive survey research design to describe the impact of global system for communications on Nigerian rural users. The study drawn on GSM subscribers whom were comprised of policemen, teachers, the unemployed graduates, petty traders and the drivers as the target population. The sample comprises of 500 respondents randomly selected from five rural communities of Rivers State, Nigeria. Their age ranged from 25- 50 years. The used data collection instrument (questionnaire) was divided into two sections. The first section required the respondents' biodata information like age, sex, and years of using GSM etc while the second section contained response items. The second section was further divided into four parts. Part 1 contains items on GSM and economic lives of the Nigerian rural users; Part 2 contains items on GSM and unemployment; while Part 3 contains items on GSM and crime reduction. Each part contains five items each, except part 2 which contains six items. These gave a total of 16 items in all. It is a likert type of points scale. Response to the items range from Strongly Agree to Strongly Disagree. The instrument was administered to the respondents in their various communities using the Town Halls as the venue of the administration. All the respondents in each of the 5 selected rural communities were intimated of the date of the administration. With the support of some research assistants, the administration was completed in 5 days. Data collected was analyzed using simple percentages.

\section{Results}

The results of the analysis are presented as follows:

Table 1: Bio-Data Information Summary

Sex
Male
Female
Total
Marital Status
Single
Married
Divorce
Total

Respondents Age in Years
$21-30$
$31-40$
$41-50$
$51+$
Total
Return Rate
Number Administered
Number Returned

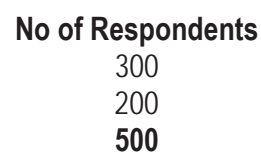

No of Respondents

175

275

50

500

No of Responses
75
200
175
50
500

Number
500
500

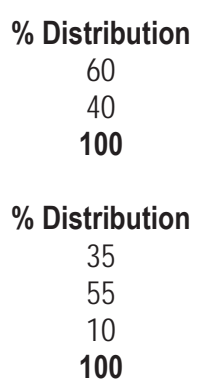

Percentage

15

40

35

10

100

Percentage

100

100

The results in table 1 above show that $60 \%$ of the respondents were male while $40 \%$ were female. Furthermore, $35 \%$ were single while $55 \%$ were married and $10 \%$ were shown to be divorcee. The result as well reveals that $80 \%$ of the respondents' age falls within the range of 21-50 years. This of course constitutes the majority. The return rate of the instrument was to $100 \%$. 


\subsection{Research Question 1: Does the introduction of GSM have impact on economic lives of the Nigerian rural user?}

Table 2:Economic Lives of the Nigerian rural users and Use of GSM

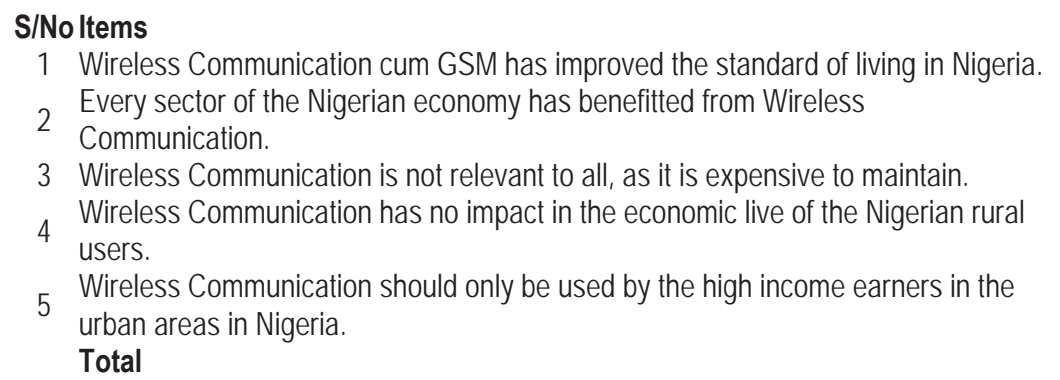

$\begin{array}{ccccc}\text { SA } & \text { A } & \text { D } & \text { SD } & \text { R-Total } \\ 60(30) & 42(35) & 14(34) & 10(27) & 126 \\ 35(22) & 40(27) & 8(25) & 11(27) & 94 \\ 6(26) & 7(28) & 52(27) & 75(40) & 140 \\ 2(18) & 5(21) & 32(23) & 37(24) & 76 \\ 14(15) & 10(17) & 25(16) & 15(18) & 64 \\ 111 & 128 & 125 & 136 & 500\end{array}$

The result in the table above indicates a significant relationship meaning that the introduction of Wireless Communication has significant impact on Nigeria rural economy.

7.2 Research Question 2: Does the introduction of Wireless Communication cum GSM provide more employment opportunities to the Nigerians in rural areas?

Table 3: Employment Opportunities and Use of GSM

\begin{tabular}{|c|c|c|c|c|c|c|}
\hline S/No & Items & SA & A & D & SD & $\begin{array}{l}\text { R- } \\
\text { Total }\end{array}$ \\
\hline 1 & $\begin{array}{l}\text { The introduction of Wireless Communication in Nigeria encourage } \\
\text { small scale business }\end{array}$ & $46(44)$ & $36(36)$ & $6(11)$ & 15(12) & 103 \\
\hline 2 & $\begin{array}{l}\text { Wireless Communication cum GSM has provided a means of income } \\
\text { to many young school leavers. }\end{array}$ & $51(48)$ & $43(41)$ & 10(12) & 17(13) & 121 \\
\hline 3 & Wireless Communication cum GSM has reduced poverty in Nigeria. & $48(46)$ & $44(38)$ & 1012) & $6(12)$ & 108 \\
\hline 4 & $\begin{array}{l}\text { Wireless Communication has drastically reduced unemployment in } \\
\text { the rural areas. }\end{array}$ & $42(43)$ & $32(35)$ & $7(11)$ & $9(12)$ & 90 \\
\hline 5 & $\begin{array}{l}\text { GSM provides employment opportunities for only a few influential } \\
\text { Nigerians. }\end{array}$ & $8(14)$ & $8(12)$ & $9(3)$ & 10(4) & 35 \\
\hline 6 & GSM provides holiday job for many students & $8(16)$ & 10(13) & 10(4) & $10(4)$ & 33 \\
\hline & Total & 213 & 125 & 53 & 58 & 500 \\
\hline
\end{tabular}

The results in table 3 above show that the introduction of GSM has significantly created employment opportunities for the unemployed youths in the rural areas in Nigeria.

7.3 Research Question 3: Has the introduction of GSM reduced the rate of crime in Nigeria?

Table 4: Rate of crime and the use of GSM

\begin{tabular}{|c|c|c|c|c|c|c|}
\hline S/No & Items & SA & A & D & SD & $\begin{array}{c}\text { R- } \\
\text { Total }\end{array}$ \\
\hline 1 & Wireless Communication has increased the crime rate in Nigeria. & $13(38)$ & $16(22)$ & 4333) & $48(38)$ & 120 \\
\hline 2 & GSM encourages dishonesty among Nigerians. & $12(23)$ & 9(19) & $45(29)$ & $38(33)$ & 104 \\
\hline 3 & $\begin{array}{l}\text { The use of GSM assists in reporting criminals in the society to Law } \\
\text { Enforcement Agents }\end{array}$ & $68(18)$ & $44(25)$ & $6(37)$ & $16(42)$ & 134 \\
\hline 4 & Armed robbery activities have been aided by GSM. & $13(22)$ & 10(18) & $33(26)$ & $39(30)$ & 95 \\
\hline \multirow[t]{2}{*}{5} & $\begin{array}{l}\text { There has been a dramatic increase of fraudulent activities in } \\
\text { Nigeria due to Wireless Communication. }\end{array}$ & $7(11)$ & 12(9) & $11(13)$ & $17(15)$ & 47 \\
\hline & Total & 112 & 92 & 138 & 158 & 500 \\
\hline
\end{tabular}

The result in table 4 above shows that the introduction of GSM in Nigeria has actually reduced the rate of crime, 
especially in the rural areas where crimes can now be reported promptly.

\section{Discussion}

While the major focus of this paper was on impact of Wireless Communication system on theeconomic lives of rural communities in Nigeria, attempt was made to examine this impact on specific issues such as income, employment opportunities, crime and security. Perhaps, the first major observation that should be made is that the introduction of the GSM into Nigeria has actually radicalized the space of information and communication among the generality of Nigerians. Within a period of about 13 years, a large percentage of Nigerians, including those in the rural communities now have access to this communication mode. Whereas in the late 1980s, a particular minister of communication, a top government functionary in Nigeria, made a remarkable statement that "telephone is not for poor" today in Nigeria both the 'Rich' and the 'Poor' have access to the wireless system of mobile communication.

Telephoning has since been removed as the exclusive preserve of the rich in Nigeria with the introduction of GSM. This significant observation underlines the major finding in this study.

On the impact of GSM on employment creation for rural people, it is reported in this study that a majority of school leavers, who till now have been idle and not gainfully employed now engage themselves in retailing of GSM products and as local service providers. Due to the small capital required to set up such a business, many who were unemployed before now enter into such businesses. This has reduced the number of unemployed youths in our cities and rural communities.

Consequent upon these employment creation opportunities for rural people is the resultant increase in their income level. With little earnings coming from the retailing of GSM products and call services, the respondents indicated that the introduction of GSM into the country has enhanced their income level. The category of respondents being described here are the people at the lowest divide of the societal ladder such as farmers, petty traders, teachers, (at both primary and secondary schools levels), generally what could be described as the low income earners. Although, it was very difficult for the respondents to give precise figures of their income, they generally acknowledge that their income has been enhanced due to GSM effect. As reported in the literature, therefore, the introduction of the GSM into Nigeria has directly or indirectly impacted on the economic lives of the Nigerian rural users.

With regards to GSM and crime rates, it was reported that the introduction of GSM has significant impact on crime reporting in the rural areas in Nigeria. It could be noted that crime detection and report to law enforcement agencies have improved. In fact a particular GSM operator provides a service that could help trace stolen vehicles in the country. This service has led to the recovery of many stolen cars in the country. It should also be noted that the category of people sampled in the study are from the rural areas, hence, they may not be able to access such services yet. On the whole, it could be concluded that the introduction of GSM communication in Nigeria has greatly enhanced trade and business, and the general income of the Nigerian rural communities.

With many service providers coming on board and expansion of network services even among the existing service providers, things could only get better. It is therefore expected that access will be extended to more rural communities in Nigeria and in no distant future the whole country would have been covered. This will have multiplier effects on the life of the people generally, and the rural dwellers more specifically.

\section{Summary}

Wireless Communications are having a positive impact in Nigeria by attracting investment and developing various commercial activities.

We, summarize that the top five conclusions of our study are as follows:

- Wireless Communication has ample reach in Nigeria and will continue to post rapid growth.

Mobile Communication subscriptions surpassed 72.6 Million as at year 2009 resulting in a penetration rate of $50 \%$ of the population which the subscriptions have surpassed 128 Million by end of 2013 , creating a substantial user base for the development of the mobile applications market.

- The mobile industry is having a positive economic impact by generating substantial investment in infrastructure and employing a significant number of Nigerians especially from the rural communities.

During the past decade, approximately $\$ 16$ billion has been invested in projects related to mobile services.

There are as many as 3 Million jobs directly and indirectly related to mobile services in the country. Nigerian end users agree that wireless communication have favourably influenced every aspect of their lives:

- Nigerian end users agree that wireless communication have positively influenced every aspect of their lives, 
enabling them to connect with different people, access information, create business opportunities, lower transaction costs and enhancing social interaction.

- It was also identified that numerous examples of initiatives using public and private funding that leverage wireless communication mobile services in social programs, improve the operation of various vertical industries and foster connectivity in remote areas.

- The future development of the mobile market in Nigeria will be driven by collaboration among industry players, the local government and international organizations. End users in Nigeria value mobile services greatly and are frequent users of this platform, yet the availability of specific mobile data-based applications is still limited. Developing a set of tools and information systems will require close collaboration among local and international entities; telecom vendors and operators can play a key role in importing successful initiatives to Nigeria.

\section{References}

Adomi, E. A. (2006). Mobile phone usage: Patterns of library and information science students at Delta State University, Abraka, Nigeria. Electronic Journal of Academic and Special Librarianship 7(1), 1-11.

Ajakaye, T. A. (2005). Telecommunications Business in Nigeria, University of Lagos.

Audile, N. O. (2000, November 7). Matters Arising on Mobile Wireless Licensing. The Guardian, p. 41.

Balogun, J. (2000). Impact of GSM on Economy and Development, Center for Culture and Technical Interchange between East and West, Gwalada Abuja.

Blake, M. (2004).Growing mobile market in Africa. The Electronic Library, 22(4), 370.

Huel, J. L. (2003). GSM will Reach its Targets. Alcatel Telecommunications Review.

International Engineering Consortium (2005). Global system for mobile communication (GSM) definition \& overview. Retrieved May 10, 2006, from http://www.iec.org/online/tutorials/gsm

International Engineering Consortium (2005). Global system for mobile communication (GSM)definitions and overview. Retrieved May 10, 2006, from http://www.iec.org/online/tutorials/gsm

Masiyiwa, A. (2001). Econet in West Africa.Microsoft Encarta Encyclopedia Microsoft.

Moholi, P. (2005). Wireless Africa. The Guardian, pp 41-46.

Nigerian Businessinfo.com (2003).Revisiting Nigeria's telecommunications industry. Retrieved May 12, 2006, from http://www.nigriabusinessinfo.com/telecoms080903.htm

Okoruwa, C. (2004). Three years of GSM. The Guardian, p. 5.

Radio Electronics (2006).GSM tutorial \{1\}: a technical overview of tutorial of the GSM (Global System for Mobile communication). Retrieved May 12, 2006, from lectrhttp://www.radioeonics.com/info/cellulartelecoms/gsm_introduction.pdf

Scotts, N. (2004). New research findings point to high rates of phone use in no or low service areas. Retrieved May 12, 2006, from http://www.balancingact-africa.com/news/back/balancing-act_203.html

Wojuade, J. I. (2005). Impact of global system for mobile telecommunication on Nigerian Economy: A case of some selected local government areas in Oyo State, Nigeria. A Med Thesis. University of Ibadan, Nigeria. 